Article

\title{
Characteristics of Ions Composition and Chemical Weathering of Tributary in the Three Gorges Reservoir Region: The Perspective of Stratified Water Sample from Xiaojiang River
}

\author{
Di Wang ${ }^{1}$, Guilin Han ${ }^{1} *\left(\mathbb{D}\right.$, Bogen $\mathrm{Li}^{2}$, Mingming $\mathrm{Hu}^{3,4}$, Yuchun Wang ${ }^{3,4}\left(\mathbb{D}\right.$, Jinke Liu ${ }^{1}\left(\mathbb{D}\right.$, Jie Zeng ${ }^{1}$ (D) \\ and Xiaoqiang $\mathrm{Li}^{1}{ }^{1}$
}

1 Institute of Earth Sciences, China University of Geosciences (Beijing), Beijing 100083, China; wangdi1123@cugb.edu.cn (D.W.); liujinke@cugb.edu.cn (J.L.); zengjie@cugb.edu.cn (J.Z.); Xiaoqli@cugb.edu.cn (X.L.)

2 Yunnan Bureau of Hydrology and Water Resources, Kunming 650605, China; swzyy1@126.com

3 State Key Laboratory of Simulation and Regulation of Water Cycle in River Basin, Beijing 100038, China; humingming@iwhr.com (M.H.); wangyc@iwhr.com (Y.W.)

4 Department of Water Ecology and Environment, China Institute of Water Resources and Hydropower Research, Beijing 100038, China

* Correspondence: hanguilin@cugb.edu.cn; Tel.: +86-10-8232-3536

Citation: Wang, D.; Han, G.; Li, B.; Hu, M.; Wang, Y.; Liu, J.; Zeng, J.;

$\mathrm{Li}, \mathrm{X}$. Characteristics of Ions Composition and Chemical Weathering of Tributary in the Three Gorges Reservoir Region: The Perspective of Stratified Water Sample from Xiaojiang River. Water 2022, 14, 379. https://doi.org/ $10.3390 / w 14030379$

Academic Editors: Yuankun Wang and Feng Huang

Received: 23 December 2021

Accepted: 25 January 2022

Published: 27 January 2022

Publisher's Note: MDPI stays neutral with regard to jurisdictional claims in published maps and institutional affiliations.

Copyright: (C) 2022 by the authors. Licensee MDPI, Basel, Switzerland. This article is an open access article distributed under the terms and conditions of the Creative Commons Attribution (CC BY) license (https:// creativecommons.org/licenses/by/ $4.0 /)$.

\begin{abstract}
River water chemistry offers information on watershed weathering and responds to the global carbon cycle. Watershed weathering processes and water chemistry in stratified water are still unclear in Xiaojiang River, as a major tributary of the Three Gorges Reservoir (TGR) which is the largest reservoir in the world. Major ions of river water at different depths were measured to reveal the ionic composition and chemical weathering properties by principal component analysis and stoichiometry in Xiaojiang River. $\mathrm{Ca}^{2+}-\mathrm{HCO}_{3}{ }^{-}$dominated the hydrochemical facies of river. Surface river water had the lowest total dissolved solid $(146 \mathrm{mg} / \mathrm{L})$ compared to other layers of water. According to principal component analysis, the major ions were divided into two principal components. PC1 was the weathering end-member of rocks, including the main ions except $\mathrm{K}^{+}$and $\mathrm{NO}_{3}-\mathrm{N}$, and PC2 may be the mixed end-member of atmospheric input and anthropogenic input. From stoichiometry, carbonate weathering dominated the cationic composition, with a contribution ratio of $56.7 \%$, whereas atmospheric input (15.2\%) and silicates weathering $(13.9 \%)$ had similar extent of contribution. Compared with other major tributaries of TGR, Xiaojiang had more intense chemical weathering processes. The weathering rates of carbonates and silicates were $19.33 \pm 0.68 \mathrm{ton} / \mathrm{km}^{2} /$ year and $3.56 \pm 0.58$ ton $/ \mathrm{km}^{2} /$ year, respectively. Sulfuric acid as a proton may have participated less in the weathering processes of Xiaojiang River. The $\mathrm{CO}_{2}$ consumption budgets for silicates and carbonates weathering were $0.8 \pm 0.2 \times 10^{9} \mathrm{~mol} /$ year and $2.8 \pm 0.2 \times 10^{9} \mathrm{~mol} /$ year, respectively. These results enrich the watershed weathering information of TGR tributaries and provide data support for understanding the global carbon cycle.
\end{abstract}

Keywords: water chemistry; source apportionment; weathering rate; carbon budget

\section{Introduction}

Rivers are an important part of the Earth's critical zone because they connect the terrestrial and oceanic ecosystems [1]. Because of a close relationship with the global carbon cycle, the migration and transformation of terrigenous material from rivers to oceans have attracted extensive attention [2-4]. Chemical weathering of rocks is a key source of river solutes and affects $\mathrm{CO}_{2}$ levels throughout geological time [5-7]. $\mathrm{CO}_{2}$ from the atmosphere and soil respiration takes part in weathering processes and enters rivers as dissolved inorganic carbon (DIC) [8,9]. Therefore, the chemical mass balance of dissolved and particulate phases can provide critical information about the carbon storage potential 
of the river basin. According to recent research, in addition to atmospheric input and local lithology, human activities (e.g., agricultural irrigation and damming) can influence ionic composition and interfere with chemical weathering processes [10-13], further affecting the global carbon cycle [14-16]. Hence, describing the geochemical processes of river solutes at local and regional scales is critical to the carbon cycle and long-term global climate change.

The Three Gorges Reservoir (TGR) is located in Chongqing and Hubei province in southwest China, regulating 56\% of Asia's largest river (the Yangtze River) [17]. Because the TGR is the largest reservoir in the world, and more than half of the basin is covered by carbonates, it is suitable for quantifying the impacts of dams on stream geochemistry and carbon cycle [18-20]. The reservoir impoundment management can change the residence time, flow direction, and level of river water, and further affect the processes of water-rock interaction [21,22]. The major ions composition of river water contains important information about chemical weathering [23-25], water supply [26,27], and human activities [28-30], all of which are essential for understanding the damming influences on the material cycle and climate change in the basin $[13,31]$. Previous studies have shown that the major ionic composition of TGR's main channel was dominated by rock weathering processes [32-34], and the $\mathrm{CO}_{2}$ consumption of silicates and carbonates in TGR account for about $1 \%$ of the world's $\mathrm{CO}_{2}$ consumption of silicates and carbonates, respectively [29,35]. Some tributaries in TGR also have high weathering rates [36-38], e.g., Chetelat et al. [29] reported that the cationic carbonate weathering rate of Wujiang and Jialingjiang were about $10 \mathrm{ton} / \mathrm{km} /$ year and 6 ton $/ \mathrm{km}^{2} /$ year, respectively, which were close to the cationic carbonate weathering rate of the Yangtze River (10 ton $/ \mathrm{km}^{2} /$ year) at TGD. These results indicate that the carbon sink capacity of tributaries cannot be ignored. Hence, research into hydrochemistry and weathering processes of tributaries in the TGR requires more attention.

Xiaojiang River, as the largest tributary in the middle of the TGR, has attracted extensive attention due to water quality problems $[39,40]$. However, a description of the major ions composition and chemical weathering processes in the Xiaojiang River is still lacking. Previous studies have shown that the hydrological process and geochemical cycle of elements in Xiaojiang River were affected by the storage regulation resulting from the construction of the Three Gorges Dam (TGD), including hydrodynamic characteristics, nutrient dynamics, and $\mathrm{CO}_{2}$ flux $[21,41,42]$. These studies also showed that river water at different depths had different geochemical condition. Therefore, the major ions composition of stratified river water may contain additional information about chemical weathering processes, and this has not been described in previous studies. Hence, this study investigated the ionic composition of river water at different depths of Xiaojiang River, combined with principal component analysis and chemometrics, with the goal of revealing (1) the content and spatial distribution of major ions in stratified river water, (2) source apportionment of ions, and (3) chemical weathering rates and $\mathrm{CO}_{2}$ consumption in the basin. This study fills the gap in the understanding of weathering in the Xiaojiang River and provides data support for understanding the impacts of the damming on global climate change.

\section{Study Area and Methods}

\subsection{Location of Study Area}

The Xiaojiang River straddles the longitude of $107^{\circ} 44^{\prime} 50^{\prime \prime}-108^{\circ} 53^{\prime} 56^{\prime \prime} \mathrm{E}$ and the latitude of $30^{\circ} 39^{\prime} 35^{\prime \prime}-31^{\circ} 41^{\prime} 19^{\prime \prime} \mathrm{N}$. It is the largest tributary in the north bank of the middle TGR, and the total area of the basin is $5225 \mathrm{~km}^{2}$. The Xiaojiang River basin belongs to the subtropical humid monsoon climate zone, with an average annual temperature of $18.2^{\circ} \mathrm{C}$ [43]. The annual precipitation and discharge are $1300 \mathrm{~mm}$ and $127 \mathrm{~m}^{3} / \mathrm{s}$, respectively, and the flood season (from May to September) accounts for about $75 \%$ of the annual discharge [44]. The Xiaojiang River is $182 \mathrm{~km}$ long and flows from north to south into the main stream (the Yangtze River) of the TGR. Mainly carbonate and clastic rocks constitute the geology of the Xiaojiang River basin, including limestone, sandstone, mudstone, siltstone interlayered with shale, and coal seams [45]. Due to the geological background and 
human activities (slope tillage and urbanization), soil erosion is a serious problem in the basin [46].

\subsection{Sample Collection and Treatment}

As shown in Figure 1, in August 2020, water samples were collected from six sites in the downstream of the Xiaojiang River. Global Positioning System was applied to measure the longitude and latitude of each site. Water samples were collected at three depths in the center of the river channel: surface (50 cm depth), middle ( $1 / 2$ water depth), and bottom. Then, all samples were filtered through the cellulose acetate membranes on the day of sampling $(0.22 \mu \mathrm{m})$, and they were stored in high-density polyethylene bottles. Highly purified nitric acid was dropped into the samples used for cationic test to keep the $\mathrm{pH}<2$. All parameters of samples were measured within one week after being filtered.

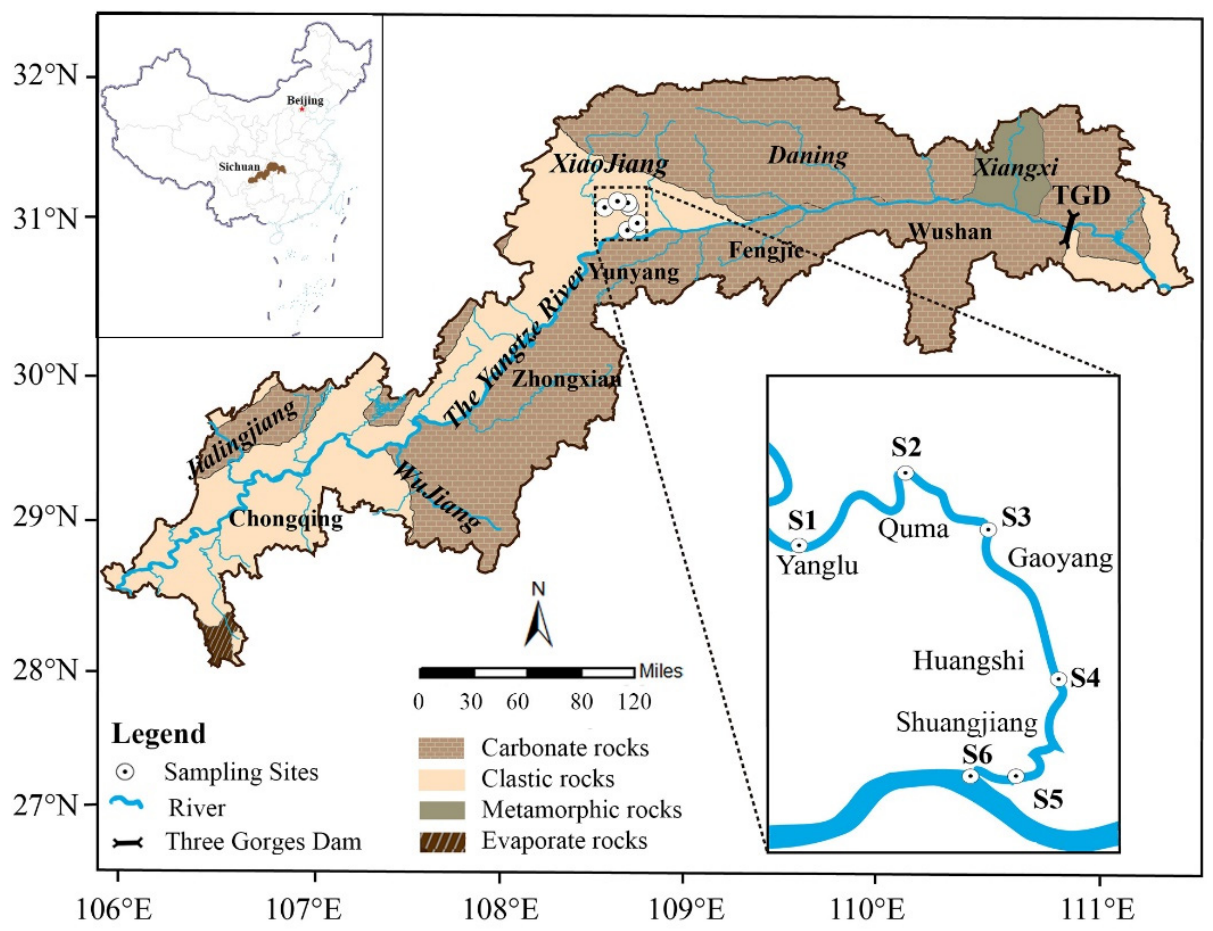

Figure 1. The lithologic distribution and sampling sites of Xiaojiang River in the TGR.

\subsection{Measurement of Parameters}

Total dissolved solids (TDS), electrical conductivity (EC), and temperature measurements were performed in the field at the time of sampling with a portable multiparameter instrument (YSI Inc., Yellow Springs, OH, USA). PH values were measured with a pH meter (Rex., Shanghai, China). Ion chromatograph (Dionex ICS-600, Thermo Fisher Scientific Inc., Sunnyvale, CA, USA) and inductively coupled plasma optical emission spectrometer (Optima 5300DV, PerkinElmer Inc., Waltham, MA, USA) were used to determine the concentrations of major anions $\left(\mathrm{F}^{-}, \mathrm{NO}_{3}-\mathrm{N}, \mathrm{Cl}^{-}\right.$, and $\left.\mathrm{SO}_{4}{ }^{2-}\right)$ and cations $\left(\mathrm{Na}^{+}, \mathrm{K}^{+}, \mathrm{Mg}^{2+}\right.$, and $\left.\mathrm{Ca}^{2+}\right)$, respectively. During measurement, blanks, duplicate samples, and national standard materials (GBW08606 and GBW082051, National Research Center for Certified Reference Materials, China) were used to correct the test to ensure the accuracy of the data (the deviation was $<5 \%$ throughout the analysis). The total alkalinity of water samples was determined by titration with hydrochloric acid. According to Hunt et al. [47], the content of $\mathrm{HCO}_{3}{ }^{-}$can be calculated by linear relationship between $\mathrm{pH}$ and alkalinity. The calculation formula is as follows:

$$
\mathrm{wHCO}_{3}{ }^{-}=-0.5 \times \mathrm{pH}+3.79
$$




\subsection{Measurement of Contribution Ratio}

Due to changes in the water level caused by dam regulation or the passage of flood peaks of main channel, water from the main stream may recharge into its tributaries [27]. The area where the tributaries are affected by the main stream is called the confluence zone [26]. In this confluence zone, the major ions composition of the tributary is not only affected by upstream inflow, but also contributed to by the main stream. Therefore, the contribution ratio refers to the proportion of discharge from main channel to the confluence zone and can be quantified by the concentration of main ions in conservative behavior. The formula is [26]

$$
\delta_{\mathrm{M}}=\mathrm{x} \delta_{\mathrm{T}}+(1-\mathrm{x}) \delta_{\mathrm{U}}
$$

where $\mathrm{x}$ is the contribution ratio of discharge from TGR main channel; $1-\mathrm{x}$ is the contribution ratio of the discharge from upper reach in Xiaojiang River. $\delta_{\mathrm{T}}, \delta_{\mathrm{U}}$, and $\delta_{\mathrm{M}}$ represent ionic concentration of the TGR main channel, the upper reach, and confluence zone of Xiaojiang River, respectively.

\subsection{Measurement of Chemical Weathering Rate and $\mathrm{CO}_{2}$ Consumption}

Cationic weathering rate (ton $/ \mathrm{km}^{2} /$ year) was used to evaluate the degree of rock weathering in Xiaojiang River basin [48]. The calculation formulas were as follows:

$$
\begin{gathered}
\Phi_{\text {sili }}=\left[\mathrm{Na}^{+}\right]_{\text {sili }}+\left[\mathrm{K}^{+}\right]_{\text {sili }}+\left[\mathrm{Ca}^{2+}\right]_{\text {sili }}+\left[\mathrm{Mg}^{2+}\right]_{\text {sili }} \\
\Phi_{\text {carb }}=\left[\mathrm{Ca}^{2+}\right]_{\text {carb }}+\left[\mathrm{Mg}^{2+}\right]_{\text {carb }}
\end{gathered}
$$

where sili and carb are silicate weathering and carbonate weathering, respectively. The contribution concentrations of carbonate and silicate weathering to cations were calculated based on the forward model.

According to Chetelat et al. [29], the content of $\left[\mathrm{SO}_{4}{ }^{2-}\right]\left(\Phi_{\mathrm{SO} 4}\right)$ that is involved in rock weathering should theoretically be the difference between $\left[\mathrm{HCO}_{3}{ }^{-}\right]$and the sum of cations derived from silicate and carbonate weathering, and $\Phi_{\mathrm{SO} 4}$ should follow the formulas below:

$$
\begin{gathered}
{\left[\mathrm{SO}_{4}{ }^{2-}\right]_{\text {sili }}=0.5\left[\mathrm{Na}^{+}\right]_{\text {sili }}+0.5\left[\mathrm{~K}^{+}\right]_{\text {sili }}+\left[\mathrm{Ca}^{2+}\right]_{\text {sili }}+\left[\mathrm{Mg}^{2+}\right]_{\text {sili }}} \\
{\left[\mathrm{SO}_{4}{ }^{2-}\right]_{\text {carb }}=0.5\left[\mathrm{Ca}^{2+}\right]_{\text {carb }}+0.5\left[\mathrm{Mg}^{2+}\right]_{\text {carb }}}
\end{gathered}
$$

If the $\Phi_{\mathrm{SO} 4}$ was assumed to be entirely derived from silicate weathering, the cations derived from silicate weathering and $\mathrm{CO}_{2}$ consumption were calculated as follows:

$$
\begin{aligned}
& {\left[\mathrm{Na}^{+}\right]_{\text {sili }}^{\mathrm{ssw}}=\Phi_{\mathrm{SO} 4} \times\left[\left(\frac{\left[\mathrm{Ca}^{2+}\right]}{\left[\mathrm{Na}^{+}\right]}\right)_{\text {sili }}+\left(\frac{\left[\mathrm{Mg}^{2+}\right]}{\left[\mathrm{Na}^{+}\right]}\right)_{\text {sili }}+\left(\frac{\left[\mathrm{K}^{+}\right]}{\left[\mathrm{Na}^{+}\right]}\right)_{\mathrm{sili}}+0.5\right]^{-1}} \\
& {\left[\mathrm{~K}^{+}\right]_{\text {sili }}^{\text {ssw }}=\left[\mathrm{Na}^{+}\right]_{\text {sili }}^{\text {ssw }} \times\left(\frac{\left[\mathrm{K}^{+}\right]}{\left[\mathrm{Na}^{+}\right]}\right)_{\text {sili }}} \\
& {\left[\mathrm{Ca}^{2+}\right]_{\text {sili }}^{\text {ssw }}=\left[\mathrm{Na}^{+}\right]_{\text {sili }}^{\text {ssw }} \times\left(\frac{\left[\mathrm{Ca}^{2+}\right]}{\left[\mathrm{Na}^{+}\right]}\right)_{\text {sili }}} \\
& {\left[\mathrm{Mg}^{2+}\right]_{\text {sili }}^{\text {ssw }}=\left[\mathrm{Na}^{+}\right]_{\text {sili }}^{\text {ssw }} \times\left(\frac{\left[\mathrm{Mg}^{2+}\right]}{\left[\mathrm{Na}^{+}\right]}\right)_{\text {sili }}} \\
& \mathrm{X}_{\text {sili }}^{\mathrm{csw}}=\mathrm{X}_{\mathrm{sili}}-\mathrm{X}_{\text {sili }}^{\mathrm{ssw}} \\
& \mathrm{CO}_{2 \text { sili }}=2\left[\mathrm{Ca}^{2+}\right]_{\text {sili }}^{\mathrm{csw}}+2\left[\mathrm{Mg}^{2+}\right]^{\mathrm{csw}}{ }_{\text {sili }}+\left[\mathrm{Na}^{+}\right]_{\text {sili }}^{\mathrm{csw}}+\left[\mathrm{K}^{+}\right]^{\mathrm{csw}}{ }_{\text {sili }}
\end{aligned}
$$

Similarly, if $\Phi_{\mathrm{SO} 4}$ was totally involved in carbonate weathering, then

$$
\left[\mathrm{Ca}^{2+}\right]_{\text {carb }}^{\mathrm{scw}}=\Phi_{\mathrm{SO} 4} \times\left[0.5\left(\frac{\left[\mathrm{Mg}^{2+}\right]}{\left[\mathrm{Ca}^{2+}\right]}\right)_{\mathrm{carb}}+0.5\right]^{-1}
$$




$$
\begin{gathered}
{\left[\mathrm{Mg}^{2+}\right]^{\mathrm{scw}}{ }_{\text {carb }}=\left[\mathrm{Ca}^{2+}\right]^{\mathrm{scw}}{ }_{\text {carb }} \times\left(\frac{\left[\mathrm{Mg}^{2+}\right]}{\left[\mathrm{Ca}^{2+}\right]}\right)_{\mathrm{carb}}} \\
\mathrm{X}^{\mathrm{ccw}}{ }_{\text {carb }}=\mathrm{X}_{\mathrm{carb}}-\mathrm{X}^{\mathrm{scw}}{ }_{\text {carb }} \\
\mathrm{CO}_{2 \mathrm{carb}}=\left[\mathrm{Ca}^{2+}\right]^{\mathrm{ccw}}{ }_{\text {carb }}+\left[\mathrm{Mg}^{2+}\right]^{\mathrm{ccw}}{ }_{\text {carb }}
\end{gathered}
$$

where SSW and SCW represent silicate and carbonate weathering with sulfuric acid participation, and CSW and CCW represent silicate and carbonate weathering with $\mathrm{CO}_{2}$ participation, respectively. $\mathrm{X}$ is the cationic concentration that is contributed from weathering of carbonates or silicates.

\subsection{Statistical and Spatial Analysis}

ArcGIS 10.4 GIS (ESRI ${ }^{\circledR}$ ) software (Environmental Systems Research Institute; Redlands, CA, USA) was used to show the spatial distribution of sampling points and geological background. A Piper diagram was generated using the "three-line diagram" function of the Origin 2018 software. The vertical concentration distribution of river major ions was shown using the function of "Cubic Spline Interpolation" by Surfer 15 software. Principal component analysis (PCA) was performed by SPSS 25.0. The software Origin 2018 (Origin Lab., Hampton, MA, USA) and Adobe Illustrator 2018 (Adobe Inc., San Jose, CA, USA) were applied to make figures.

\section{Results and Discussion}

\subsection{Hydrochemical Characteristics of Xiaojiang River}

Tables 1 and S1 displays information on the hydrochemical parameters of water samples. During the sampling period, the $\mathrm{pH}$ values of samples were between 7.50 and 7.95 , indicating a weakly alkaline river water. The values of TDS and EC gradually increased along the river. The average TDS value $(156 \mathrm{mg} / \mathrm{L})$ was lower than the main channel of TGR (292 mg/L) reported by Wang et al. [32] and some other major tributaries of TGR, such as Daning River (250 mg/L) [27], Jialingiiang River (261 mg/L) [29], and Wujiang River (355 mg/L) [49]. These results may be related to the difference in chemical weathering process and the degree of anthropogenic input. As for major ions, the absolute values of normalized inorganic charge balance of most samples were $\leq 10 \%$, suggesting that the ions in samples were basically balanced, and the data were reliable. $\mathrm{HCO}_{3}{ }^{-}$and $\mathrm{Ca}^{2+}$ concentrations dominated the anions and cations in river water, respectively. Water quality is closely linked to environmental safety and human health [50-52]. The urbanization of the Xiaojiang River basin has reached 39.4\%, with a total population of nearly 300,000 [39]. Thus, the quality of drinking water needs attention persistently. The concentrations of major ions in the Xiaojiang River were substantially lower than those reported by the WHO, indicating that the river poses a low health risk to humans.

Table 1. The hydrochemical parameters in Xiaojiang River $(n=18)$.

\begin{tabular}{cccccc}
\hline Parameters & Detection Limit & Range & Mean & \pm SD & WHO $^{\text {a }}$ \\
\hline$\left[\mathrm{F}^{-}\right](\mathrm{mmol} / \mathrm{L})$ & 0.03 & $0.01-0.03$ & 0.01 & 0.01 & 0.08 \\
{$\left[\mathrm{Cl}^{-}\right](\mathrm{mmol} / \mathrm{L})$} & 0.04 & $0.08-0.65$ & 0.28 & 0.23 & 7.05 \\
{$\left[\mathrm{NO}_{3}-\mathrm{N}\right](\mathrm{mmol} / \mathrm{L})$} & 0.06 & $0.00-0.09$ & 0.01 & 0.02 & 0.18 \\
{$\left[\mathrm{SO}_{4}^{2-}\right](\mathrm{mmol} / \mathrm{L})$} & 0.10 & $0.12-0.47$ & 0.26 & 0.14 & 3.12 \\
{$\left[\mathrm{HCO}_{3}-\right](\mathrm{mmol} / \mathrm{L})$} & - & $1.81-2.51$ & 2.21 & 0.25 & - \\
{$\left[\mathrm{Na}^{+}\right](\mathrm{mmol} / \mathrm{L})$} & 0.03 & $0.15-0.72$ & 0.37 & 0.23 & - \\
{$\left[\mathrm{K}^{+}\right](\mathrm{mmol} / \mathrm{L})$} & 0.01 & $0.06-0.08$ & 0.07 & 0.01 & - \\
{$\left[\mathrm{Ca}^{2+}\right](\mathrm{mmol} / \mathrm{L})$} & 0.04 & $0.82-1.17$ & 1.00 & 0.12 & - \\
{$\left[\mathrm{Mg}^{2+}\right](\mathrm{mmol} / \mathrm{L})$} & 0.01 & $0.16-0.41$ & 0.27 & 0.09 & - \\
$\mathrm{TDS}^{\mathrm{b}}(\mathrm{mg} / \mathrm{L})$ & 1 & $118-202$ & 156 & 20 & 1000 \\
$\mathrm{EC}^{\mathrm{c}}(\mu \mathrm{s} / \mathrm{cm})$ & 1 & $211-360$ & 277 & 20 & - \\
$\mathrm{pH}$ & 0.1 & $7.50-7.95$ & 7.75 & 1.8 & $6.5-8.5$
\end{tabular}

a WHO representative guidelines for drinking water quality, published by World Health Organization in 2017 -: No values. ${ }^{\mathrm{b}}$ TDS: Total dissolved solids. ${ }^{\mathrm{c}}$ EC: Electrical conductivity. 
The hydrochemical types of water in Xiaojiang Rivers was $\mathrm{Ca}^{2+}-\mathrm{HCO}_{3}{ }^{-}$(Figure 2). Concentration of $\mathrm{HCO}_{3}{ }^{-}$dominated the anions, followed by $\mathrm{Cl}^{-}+\mathrm{SO}_{4}{ }^{2-}$. The order of cations was $\mathrm{Ca}^{2+}>\mathrm{Na}^{+}+\mathrm{K}^{+}>\mathrm{Mg}^{2+}$. The ionic features of the Xiaojiang River were found to be similar to the Jialingjiang River and Wujiang River $[29,53]$. The solute variations of the Xiaojiang River were also consistent with the Yangtze River reported in other studies. Compared to other big rivers in China, the contents of ions $\left(\mathrm{Cl}^{-}+\mathrm{SO}_{4}{ }^{2-}\right.$ and $\left.\mathrm{Na}^{+}+\mathrm{K}^{+}\right)$ that related to the dissolution process of evaporites in Xiaojiang River were lower than that of the Jiulongiiang River [54] and Yellow River [55], while the concentration of ions $\left(\mathrm{Ca}^{2+}\right.$ and $\left.\mathrm{HCO}_{3}{ }^{-}\right)$that related to carbonate weathering were higher. These results were consistent with the geological background of rivers, where evaporites are mostly exposed in Jiulongjiang River basin, and carbonates are predominant in Xiaojiang River. Overall, similar to other rivers, the ionic composition of river water in Xiaojiang River should be mainly controlled by rock weathering during the wet season.

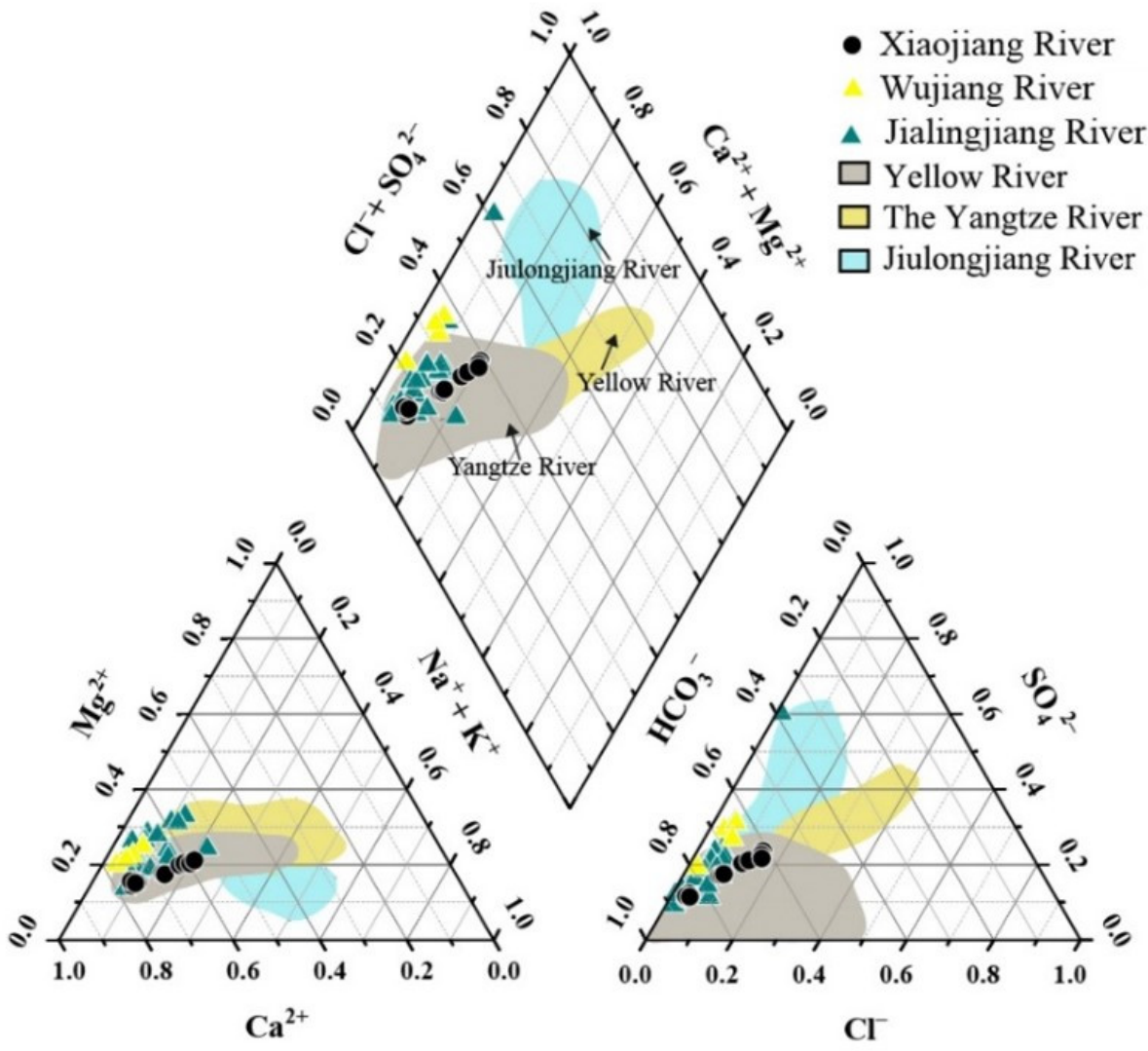

Figure 2. Piper's graph of Xiaojiang River. The data of Wujiang River [53], Jialingjiang River [33], Yangtze River [32], Yellow River [55], and Jiulongjiang River [54] in the figure are surface water data during the wet season reported by previous studies.

Figure 3 shows the vertical and transverse distribution of major ions in river water. $\mathrm{F}^{-}$is mainly affected by rainfall and coal burning in factories $[29,56]$. The range of $\mathrm{F}^{-}$ in Xiaojiang River was similar to the main stream of TGR $(0.06-0.13 \mathrm{mmol} / \mathrm{L})$ reported by Chetelat et al. [29]. They suggested that this range of $\mathrm{F}^{-}$concentration was almost unaffected by human activities and could represent the natural background value. $\mathrm{NO}_{3}-\mathrm{N}$ was mainly derived from agricultural fertilization and industrial wastewater [54]. The maximum value of $\mathrm{NO}_{3}-\mathrm{N}$ in this study was close to the mean value $(0.04 \mathrm{mmol} / \mathrm{L})$ of TGR rainfall reported in a recent study [57]. The above results indicate that there was no risk of fluoride and nitrate contamination in the river water of the study area during the wet season. 


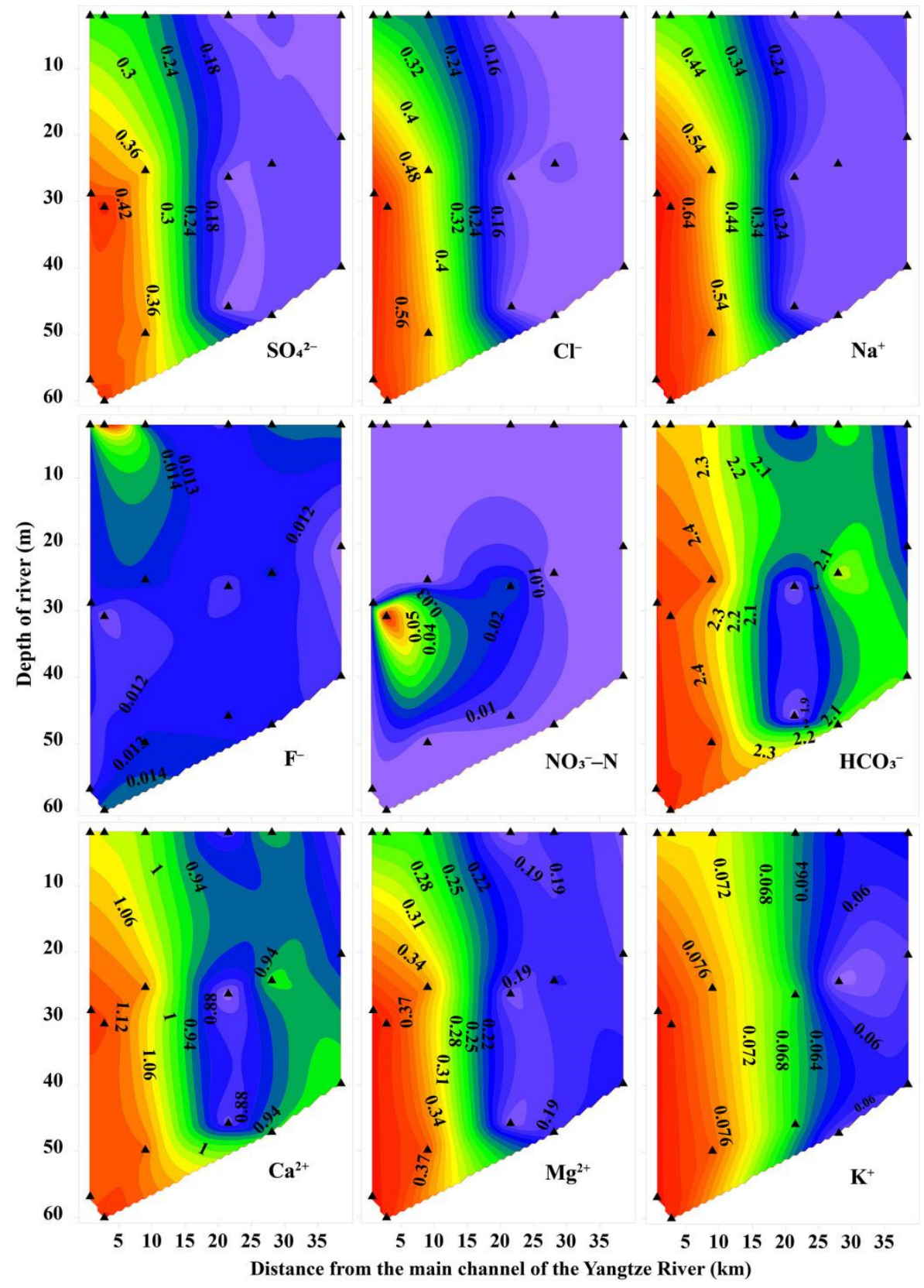

Figure 3. The vertical distribution of ionic concentrations of stratified water samples in Xiaojiang River. Black triangles represent sampling points at different depths. Higher ionic concentration is represented by red color, and the lower ionic concentration with blue color.

As for other major ions, samples closer to the Xiaojiang River mouth have higher ionic concentrations, and the concentrations of ions in most surface waters were lower than those in middle and bottom waters [58,59]. Because the river level rises as the flood crest passes through during the wet season, the river water in the main channel can flow back to the tributary and leads to a mixing process of the ions, which may eventually affect the ionic composition of the river water [60-62]. Therefore, the proportion of discharge from the main stream to tributaries can reflect the ionic contribution of the main stream to tributary. Previous studies have shown that major ions (such as $\mathrm{Cl}^{-}, \mathrm{Na}^{+}, \mathrm{Ca}^{2+}$ and $\mathrm{Mg}^{2+}$ ) have conservative behaviors during migration in water $[26,27,63]$, and can be used to trace the proportion of discharge from the main stream to the tributaries. In this study, $\mathrm{Cl}^{-}$was selected to quantify the contribution ratios of the discharge from the main channel of the TGR. The $\mathrm{Cl}^{-}$concentrations at sample S1 and S6 were assumed to be the contribution of the 
upper reach in Xiaojiang River and the concentration of main channel of TGR, respectively. As calculated by formula 2, the proportion of discharge from the main channel of the TGR to surface, middle, and bottom water in the confluence zone of Xiaojiang River were $46 \%$, $39 \%$, and $43 \%$, respectively. As tributaries close to TGD, the proportion of discharge from the TGR main stream in the confluence zone of Daning River (80.3\%) and Xiangxi River (76\%) [27] were about twice that of Xiaojiang River, indicating that the confluence zone of tributaries that close to the TGD should be more susceptible to the influence of main stream inflow.

\subsection{Source Apportionment of Riverine Ions}

\subsubsection{PCA Analysis}

PCA analysis can help classify ions of similar origin [64]. As shown in Figure 4 and Table 2, two principal components were extracted. The variances of PC1 and PC2 were $73.4 \%$ and $13.9 \%$, respectively.

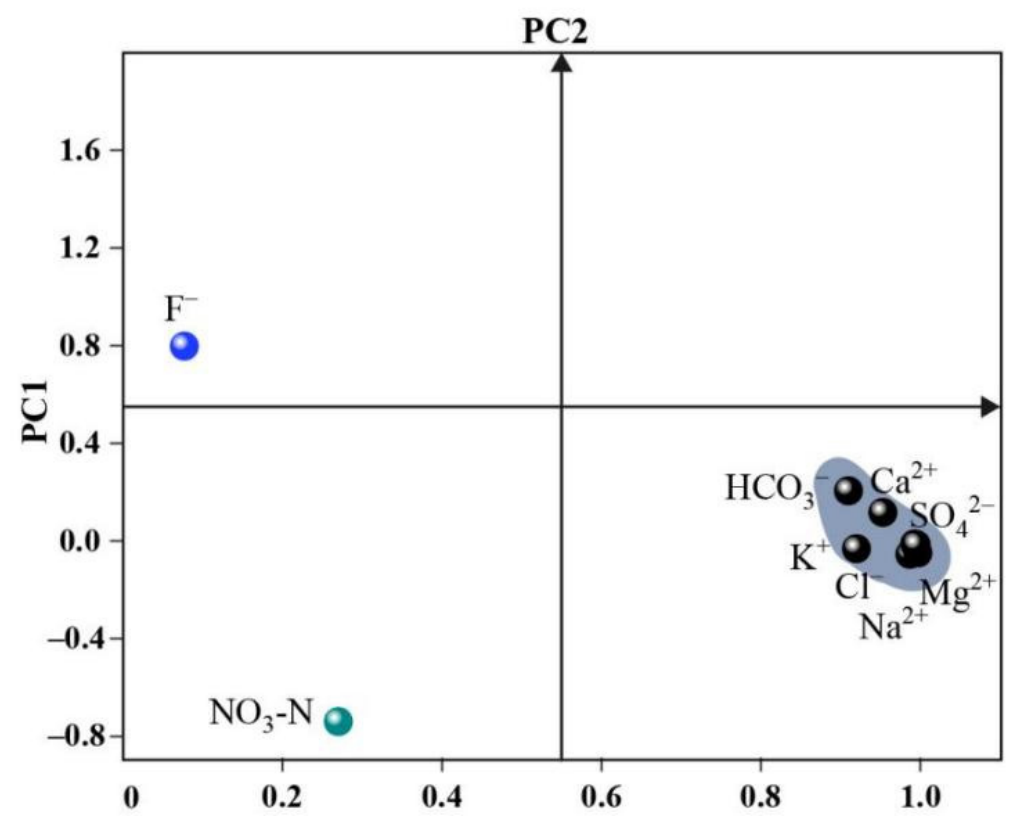

Figure 4. The principal component analysis of major ions in Xiaojiang River.

Table 2. Results of PCA analysis.

\begin{tabular}{ccc}
\hline Variable & PC1 & PC2 \\
\hline$\left[\mathrm{HCO}_{3}{ }^{-}\right]$ & 0.91 & 0.205 \\
{$\left[\mathrm{Cl}^{-}\right]$} & 0.987 & -0.055 \\
{$\left[\mathrm{NO}_{3}-\mathrm{N}\right]$} & 0.27 & -0.74 \\
{$\left[\mathrm{SO}_{4}{ }^{2-}\right]$} & 0.997 & -0.049 \\
{$\left[\mathrm{Na}^{+}\right]$} & 0.993 & -0.012 \\
{$\left[\mathrm{~K}^{+}\right]$} & 0.92 & -0.032 \\
{$\left[\mathrm{Mg}^{2+}\right]$} & 0.995 & -0.015 \\
{$\left[\mathrm{Ca}^{2+}\right]$} & 0.953 & 0.117 \\
Eigenvalues & 6.607 & 1.247 \\
Variance $(\%)$ & 73.406 & 13.885 \\
Cumulative $(\%)$ & 73.406 & 87.261 \\
\hline
\end{tabular}

PC1 has a positive loading on $\mathrm{HCO}_{3}{ }^{-}, \mathrm{Cl}^{-}, \mathrm{SO}_{4}{ }^{2-}, \mathrm{Na}^{+}, \mathrm{K}^{+}, \mathrm{Mg}^{2+}$, and $\mathrm{Ca}^{2+}$; $\mathrm{PC} 2$ has a positive loading on $\mathrm{F}^{-}$and negative loading on $\mathrm{NO}_{3}-\mathrm{N}$. Although the source analysis based on these two components was limited, the major ions related to rock weathering were positive loading with PC1. For example, the $\mathrm{Ca}^{2+}, \mathrm{Mg}^{2+}$, and $\mathrm{HCO}_{3}{ }^{-}$concentration will increase significantly during carbonate weathering [29]. $\mathrm{Na}^{+}, \mathrm{K}^{+}$, and $\mathrm{Cl}^{-}$are mainly 
derived from the weathering of evaporites and silicates [12]. Thus, PC1 should represent the end-member of the rock weathering. As discussed earlier, $\mathrm{F}^{-}$in the river is mainly from atmospheric input, and $\mathrm{NO}_{3}-\mathrm{N}$ is related to human activities (such as agricultural irrigation and industrial pollution). Therefore, PC2 should be a mixed end-member.

\subsubsection{Stoichiometry of Weathering Processes}

The ions in river water usually come from chemical weathering, anthropogenic, and atmospheric input [65-67]. As discussed previously, the major ions in Xiaojiang River should be controlled mainly by chemical weathering and be little affected by anthropogenic input. Carbonates, evaporites, and silicates are mainly distributed in the Xiaojiang River basin. The possible weathering processes are as follows [48]:

$$
\begin{array}{r}
2 \mathrm{Ca}_{x} \mathrm{Mg}_{(1-\mathrm{x})} \mathrm{CO}_{3}+\mathrm{H}_{2} \mathrm{SO}_{4} \rightarrow 2 \mathrm{Ca}^{2+}+2(1-\mathrm{x}) \mathrm{Mg}^{2+}+2 \mathrm{HCO}_{3}^{-}+\mathrm{SO}_{4}{ }^{2-} \\
\mathrm{Ca}_{x} \mathrm{Mg}_{(1-\mathrm{x})} \mathrm{CO}_{3}+\mathrm{H}_{2} \mathrm{O}+\mathrm{CO}_{2} \rightarrow \mathrm{xCa}^{2+}+(1-\mathrm{x}) \mathrm{Mg}^{2+}+2 \mathrm{HCO}_{3}{ }^{-} \\
2 \mathrm{Na}_{x} \mathrm{~K}_{(1-\mathrm{x})} \mathrm{AlSi}_{3} \mathrm{O}_{8}+\mathrm{H}_{2} \mathrm{SO}_{4} \rightarrow 2 \mathrm{xNa}^{+}+2(1-\mathrm{x}) \mathrm{K}^{+}+\mathrm{SO}_{4}{ }^{2-}+6 \mathrm{SiO}_{2}+2 \mathrm{AlOOH} \\
2 \mathrm{Na}_{x} \mathrm{~K}_{(1-\mathrm{x})} \mathrm{AlSi}_{3} \mathrm{O}_{8}+\mathrm{H}_{2} \mathrm{O}+2 \mathrm{CO}_{2} \rightarrow 2 \mathrm{xNa}^{+}+2(1-\mathrm{x}) \mathrm{K}^{+}+2 \mathrm{HCO}_{3}^{-}+6 \mathrm{SiO}_{2}+2 \mathrm{AlOOH} \\
\mathrm{CaAl}_{2} \mathrm{Si}_{2} \mathrm{O}_{8}+\mathrm{H}_{2} \mathrm{SO}_{4} \rightarrow \mathrm{Ca}^{2+}+\mathrm{SO}_{4}{ }^{2-}+2 \mathrm{SiO}_{2}+2 \mathrm{AlOOH} \\
\mathrm{CaAl}_{2} \mathrm{Si}_{2} \mathrm{O}_{8}+\mathrm{H}_{2} \mathrm{CO}_{3} \rightarrow \mathrm{Ca}^{2+}+2 \mathrm{HCO}_{3}{ }^{-}+2 \mathrm{SiO}_{2}+2 \mathrm{AlOOH}
\end{array}
$$

The sodium normalization method can be used to roughly estimate the relative contribution of evaporites, carbonates, and silicates to the composition of the major ions [29]. According to Figure 5a, water samples of Xiaojiang River were distributed between three end-members, which were similar to other tributaries of the TGR. $\mathrm{Ca}^{2+} / \mathrm{Na}^{+}$mole ratios ranged from 1 to 10 , and the mole ratios of $\mathrm{HCO}_{3}{ }^{-} / \mathrm{Na}^{+}$were between 3 and 15 . The upstream samples were closer to the carbonate end-member, and the samples near the mouth of Xiaojiang River were closer to the end-members of silicates and evaporites. These results indicated that the major ions composition of the stratified water in Xiaojiang river was mainly derived from carbonate and silicate weathering, and evaporites may contribute to the major ions in the mouth of Xiaojiang River.
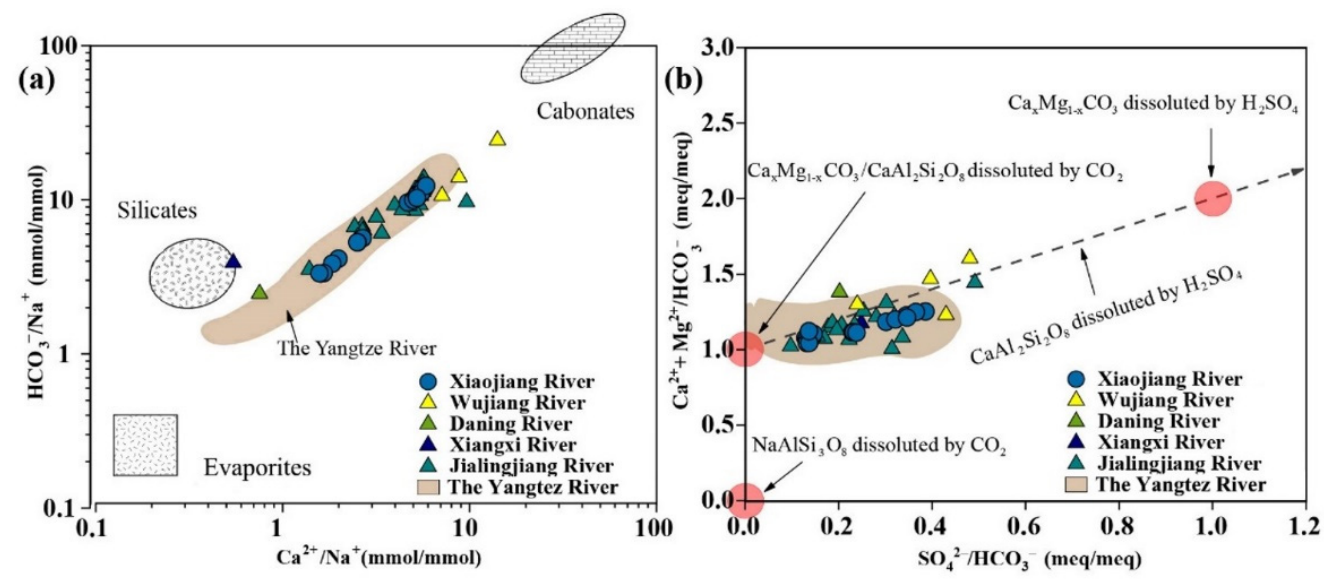

Figure 5. Mixing graph of (a) $\left[\mathrm{Ca}^{2+}\right] /\left[\mathrm{Na}^{+}\right]$and $\left[\mathrm{HCO}_{3}{ }^{-}\right] /\left[\mathrm{Na}^{+}\right]$mole ratio and $(\mathbf{b})$ mole ratios of $\left[\mathrm{SO}_{4}{ }^{2-}\right] /\left[\mathrm{HCO}_{3}{ }^{-}\right]$and $\left[\mathrm{Ca}^{2+}+\mathrm{Mg}^{2+}\right] /\left[\mathrm{HCO}_{3}{ }^{-}\right]$. The closer the samples were to an end-member, the greater the ionic ratios were affected by that end-member. The data of Wujiang River [53], Daning River [27], Xiangxi River [27], Jialingiiang River [32], and Yangtze River [33] in the figure are reported by previous studies.

Chemical weathering of rocks is known to influence the global carbon cycle and climate change $[68,69]$. Both $\mathrm{CO}_{2}$ and $\mathrm{H}_{2} \mathrm{SO}_{4}$ participate in the weathering of carbonates and sili- 
cates $[70,71]$. According to stoichiometric equations, the relationship between $\left[\mathrm{SO}_{4}{ }^{2-}\right] /\left[\mathrm{HCO}_{3}{ }^{-}\right]$ and $\left[\mathrm{Ca}^{2+}+\mathrm{Mg}^{2+}\right] /\left[\mathrm{HCO}_{3}{ }^{-}\right]$can help clarify the involvement of carbonic acid and sulfuric acid in rock weathering. If $\left[\mathrm{SO}_{4}{ }^{2-}\right] /\left[\mathrm{HCO}_{3}{ }^{-}\right]$is 1 and $\left[\mathrm{Ca}^{2+}+\mathrm{Mg}^{2+}\right] /\left[\mathrm{HCO}_{3}{ }^{-}\right]$is 1 or 0 , only $\mathrm{CO}_{2}$ is involved in mineral dissolution. If $\left[\mathrm{Ca}^{2+}+\mathrm{Mg}^{2+}\right] /\left[\mathrm{HCO}_{3}{ }^{-}\right]$is 2 and $\left[\mathrm{SO}_{4}{ }^{2-}\right] /\left[\mathrm{HCO}_{3}{ }^{-}\right]$is 1 , the minerals are dissolved by sulfuric acid. The ranges of $\left[\mathrm{SO}_{4}{ }^{2-}\right] /\left[\mathrm{HCO}_{3}{ }^{-}\right]$and $\left[\mathrm{Ca}^{2+}+\mathrm{Mg}^{2+}\right] /\left[\mathrm{HCO}_{3}{ }^{-}\right]$of Xiaojiang River were $0.1-0.5$ and $1.0-1.5$, respectively, indicating that the riverine ions originated from the minerals dissolved by both carbonic acid and sulfuric acid. In addition, the ionic ratios of samples were relatively far away from the alkali feldspar end-member, suggesting that the contribution of alkali feldspar was limited.

\subsubsection{Contribution Proportion of Weathering Sources}

A forward model was used to further clarify the proportion of ionic contribution from different sources. First, the sources of all ions were classified. Usually, $\mathrm{Ca}^{2+} \mathrm{and}^{\mathrm{Mg}} \mathrm{gg}^{2+}$ are mainly controlled by silicate and carbonate weathering [72]. $\mathrm{Na}^{+}, \mathrm{SO}_{4}{ }^{2-}$, and $\mathrm{Cl}^{-}$ are linked to the dissolution of evaporites [12]. According to the previous discussion, the influence of human input associated with agriculture and industrial wastewater on the river can be ignored. The potential sources of the major ions in the TGR were expressed as follows:

$$
\begin{gathered}
{\left[\mathrm{Cl}^{-}\right]_{\text {evaporites }}=\left[\mathrm{Na}^{+}\right]_{\text {evaporites }}} \\
{\left[\mathrm{SO}_{4}{ }^{2-}\right]_{\text {evaporites }}=\left[\mathrm{Ca}^{2+}\right]_{\text {evaporites }}} \\
{\left[\mathrm{Cl}^{-}\right]_{\text {river }}=\left[\mathrm{Cl}^{-}\right]_{\text {atmosphere }}+\left[\mathrm{Cl}^{-}\right]_{\text {evaporites }}} \\
{\left[\mathrm{K}^{+}\right]_{\text {river }}=\left[\mathrm{K}^{+}\right]_{\text {atmosphere }}+\left[\mathrm{K}^{+}\right]_{\text {silicates }}} \\
{\left[\mathrm{SO}_{4}{ }^{2-}\right]_{\text {river }}=\left[\mathrm{SO}_{4}{ }^{2-}\right]_{\text {atmosphere }}+\left[\mathrm{SO}_{4}{ }^{2-}\right]_{\text {evaporites }}+\left[\mathrm{SO}_{4}{ }^{2-}\right]_{\text {pyrites }}} \\
{\left[\mathrm{Na}^{+}\right]_{\text {river }}=\left[\mathrm{Na}^{+}\right]_{\text {atmosphere }}+\left[\mathrm{Na}^{+}\right]_{\text {evaporites }}+\left[\mathrm{Na}^{+}\right]_{\text {silicates }}} \\
{\left[\mathrm{Ca}^{2+}\right]_{\text {river }}=\left[\mathrm{Ca}^{2+}\right]_{\text {atmosphere }}+\left[\mathrm{Ca}^{2+}\right]_{\text {evaporites }}+\left[\mathrm{Ca}^{2+}\right]_{\text {silicates }}+\left[\mathrm{Ca}^{2+}\right]_{\text {carbonates }}} \\
{\left[\mathrm{Mg}^{2+}\right]_{\text {river }}=\left[\mathrm{Mg}^{2+}\right]_{\text {atmosphere }}+\left[\mathrm{Mg}^{2+}\right]_{\text {evaporites }}+\left[\mathrm{Mg}^{2+}\right]_{\text {silicates }}+\left[\mathrm{Mg}^{2+}\right]_{\text {carbonates }}}
\end{gathered}
$$

As mentioned in the previous discussion, the $\mathrm{SO}_{4}{ }^{2-}$ concentration in the Xiaojiang River far exceeds the world average for large rivers. Atmospheric input and weathering

\begin{tabular}{|c|c|c|c|c|c|c|c|c|}
\hline & $\mathrm{K}^{+} / \mathrm{Cl}^{-}$ & $\mathrm{Na}^{+} / \mathrm{Cl}^{-}$ & $\mathrm{SO}_{4}{ }^{2-} / \mathrm{Cl}^{-}$ & $\mathrm{Ca}^{2+} / \mathrm{Cl}^{-}$ & $\mathrm{Mg}^{2+} / \mathrm{Cl}^{-}$ & $\mathrm{Ca}^{2+} / \mathrm{Na}^{+}$ & $\mathrm{Mg}^{2+} / \mathrm{Na}^{+}$ & References \\
\hline \multirow{2}{*}{ Rain } & 0.55 & 0.59 & - & 1.74 & 0.56 & - & - & Wu and Han [57] \\
\hline & - & - & 2.06 & - & - & - & - & Zhang et al. [73] \\
\hline Silicates & - & - & - & - & - & 0.35 & 0.24 & Gaillardet et al. [48] \\
\hline
\end{tabular}
of gypsum and pyrite are the main sources of $\mathrm{SO}_{4}{ }^{2-}$ in river water [29]. Based on the geological background, gypsum exposure should be limited in the Xiaojiang River basin. Therefore, in addition to the atmospheric input, the remaining $\mathrm{SO}_{4}{ }^{2-}$ of Xiaojiang River was probably derived from pyrite weathering. Then, the lowest concentration of $\mathrm{Cl}^{-}$in water samples was estimated to be the $\mathrm{Cl}^{-}$values of atmospheric input, and ionic ratio of each source was referenced to previous studies (Table 3).

Table 3. Ionic ratios in the precipitation and silicates.

Contributions of different sources to cations in Xiaojiang River water are shown in Figure 6. Carbonate weathering dominated the cationic composition of river water, accounting for about $60 \%$ of the total contribution, followed by atmospheric input and silicate dissolution. Ionic contribution rates of evaporites in the reach of Huangshi-Shuangjiang (S4, S5, and S6, Figure 1) were significantly higher (about 30\%), and the proportions of middle and bottom were about twice that of surface. As discussed before, Xiaojiang River can possibly be fed by the main stream of TGR. If there are no evaporites distributed in this 
reach, and the contributions of evaporites are all from the discharge from the main stream of the TGR, the proportion of discharge from the main stream to surface, middle, and bottom water in Xiaojiang River should be about $18 \%, 36 \%$, and 37\%, respectively. However, this result contradicts the previously estimated contribution that the main stream recharges the Xiaojiang River. Thus, the mouth of Xiaojiang River should have evaporites outcrops.

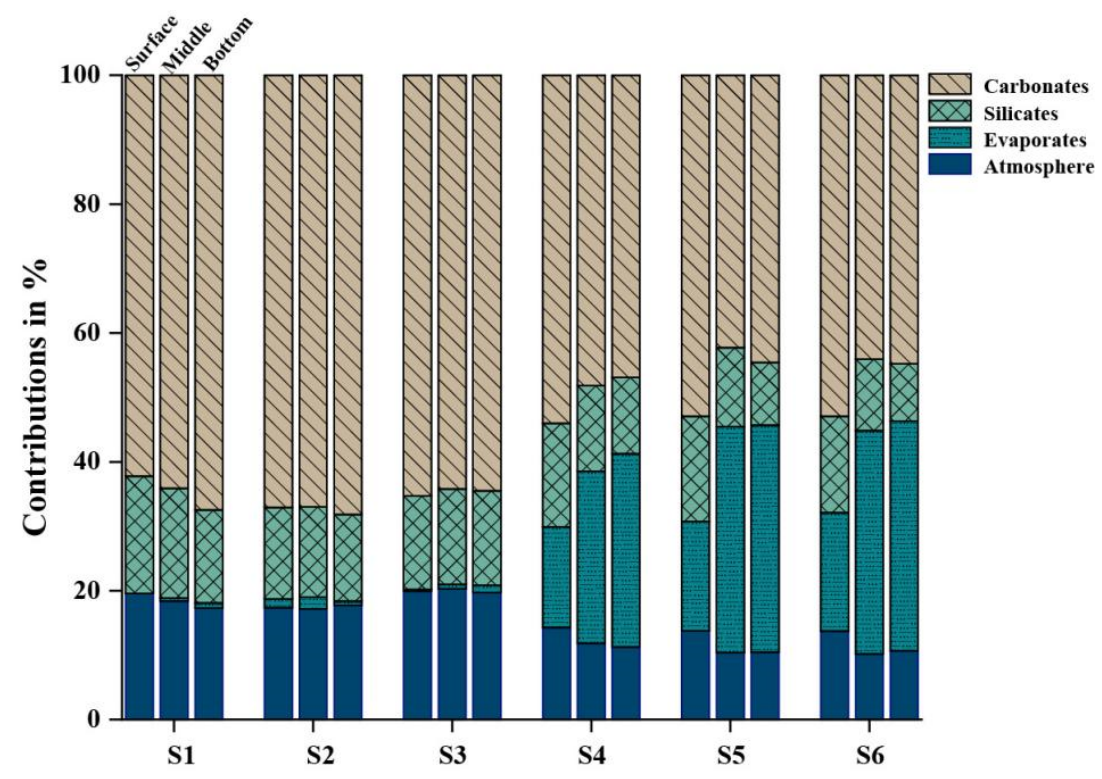

Figure 6. Contribution proportion of ions from different sources to Xiaojiang River.

\subsection{Protons of Chemical Weathering Agent and $\mathrm{CO}_{2}$ Consumption}

Details on chemical weathering rates in the Xiaojiang River basin are presented in Table 4. The total rock weathering rate of Xiaojiang River was $27.93 \pm 4.68 \times 10^{5}$ ton/year. Currently, weathering rates in two tributaries (Jialingjiang River and Wujiang River) of the TGR have been reported [29,37], and their drainage areas are more than 10 times that of Xiaojiang River. The cationic weathering rates of silicates and carbonates in Xiaojiang River $\left(3.56 \pm 0.58\right.$ ton $/ \mathrm{km}^{2} /$ year, $19.33 \pm 0.68$ ton $/ \mathrm{km}^{2} /$ year $)$ were higher than Jialingjiang River (1.2 ton $/ \mathrm{km}^{2} /$ year, 6.2 ton $/ \mathrm{km}^{2} /$ year) and Wujiang River $\left(0.69\right.$ ton $/ \mathrm{km}^{2} /$ year, 10 ton $/ \mathrm{km}^{2} /$ year), suggesting a more active weathering process. These results may be due to high elevation in the Xiaojiang River basin. Higher terrains are often accompanied by steep slopes that can accelerate rock erosion [74]. The rate of rock weathering increased from upstream to downstream, with a range from $2.72 \pm 0.03 \times 10^{5}$ ton/year to $5.14 \pm 0.85 \times 10^{5}$ ton/year. The weathering rate of evaporites in the reach of HuangshiShuangjiang was about 10 times higher than other sites, indicating more intense evaporite weathering processes occur in the mouth of Xiaojiang River.

$\mathrm{H}_{2} \mathrm{SO}_{4}$ can replace $\mathrm{CO}_{2}$ to participate the weathering process. For example, as a large tributary of the TGR, weathering processes involving sulfuric acid provide about $50 \%$ of the weathering products in the Wujiang River basin [37]. If the effect of $\mathrm{H}_{2} \mathrm{SO}_{4}$ is ignored, the $\mathrm{CO}_{2}$ consumption of rock weathering is possible to overestimate [70]. Therefore, $\mathrm{H}_{2} \mathrm{SO}_{4}$ should be considered when evaluating the $\mathrm{CO}_{2}$ consumed by rock weathering. In this study, about $27 \mu \mathrm{mol} / \mathrm{L}$ of $\mathrm{H}_{2} \mathrm{SO}_{4}$ were involved in rock weathering in the Xiaojiang River, and the contribution rate of weathering was less than $1 \%$, showing a lower effect on weathering processes. In the weathering process involving sulfuric acid, the $\mathrm{CO}_{2}$ consumption of silicates and carbonates in Xiaojiang river were $0.84 \pm 0.17 \times 10^{9} \mathrm{~mol} /$ year and $2.76 \pm 0.18 \times 10^{9} \mathrm{~mol} /$ year, respectively, and account for only about $1 \%$ of the $\mathrm{CO}_{2}$ consumption in the TGR basin reported by Chetelat et al. [29]. 
Table 4. Chemical weathering rate and $\mathrm{CO}_{2}$ consumption of small rivers.

\begin{tabular}{|c|c|c|c|c|c|c|c|c|c|c|}
\hline \multirow[b]{2}{*}{ Sample } & \multicolumn{4}{|c|}{ Silicates } & \multicolumn{4}{|c|}{ Carbonates } & \multirow{2}{*}{$\begin{array}{c}\text { Evaporites } \\
\begin{array}{c}\text { TDS evap } \\
\left(10^{5} \text { ton/year }\right)\end{array}\end{array}$} & \multirow{2}{*}{$\begin{array}{c}\begin{array}{c}\text { Total Rock } \\
\text { Weathering }\end{array} \\
\text { TDS }_{\text {total }} \mathrm{f} \\
\left(10^{5} \text { ton/year }\right)\end{array}$} \\
\hline & $\begin{array}{c}\Phi_{\text {sil }} \\
\text { (ton/km²/ } \\
\text { year) }\end{array}$ & $\begin{array}{c}\mathrm{Cat}_{\text {sil }}{ }^{\mathrm{a}} \\
\left(10^{5} \text { ton/year }^{-}\right.\end{array}$ & $\begin{array}{c}\mathrm{CO}_{2 \text { ssw }} \mathrm{b} \\
\left(10^{9} \mathrm{~mol} / \text { year }\right)\end{array}$ & $\begin{array}{c}\mathrm{CO}_{2} \mathrm{csw}^{\mathrm{c}} \\
\left(10^{9} \mathrm{~mol} / \mathrm{year}\right)\end{array}$ & $\begin{array}{c}\Phi_{\text {carb }} \\
\text { (ton/ } / \mathbf{k m}^{2} / \\
\text { year) }\end{array}$ & $\begin{array}{c}\mathrm{TDS}_{\text {carb }} \mathrm{d} \\
\left(10^{5}\right. \\
\text { ton/year })\end{array}$ & $\begin{array}{c}\mathrm{CO}_{2 \mathrm{scw}}{ }^{\mathrm{c}} \\
\left(10^{9} \mathrm{~mol} / \mathrm{year}\right)\end{array}$ & $\begin{array}{c}\mathrm{CO}_{2 \mathrm{ccw}} \mathrm{b} \\
\left(10^{9} \mathrm{~mol} / \mathrm{year}\right)\end{array}$ & & \\
\hline S1 & $3.43 \pm 0.18$ & $0.18 \pm 0.01$ & $0.70 \pm 0.05$ & $0.86 \pm 0.04$ & $18.44 \pm 1.88$ & $2.75 \pm 0.24$ & $2.46 \pm 0.33$ & $2.57 \pm 0.27$ & $0.01 \pm 0.01$ & $2.93 \pm 0.25$ \\
\hline S2 & $2.95 \pm 0.24$ & $0.15 \pm 0.01$ & $0.74 \pm 0.05$ & $0.74 \pm 0.05$ & $20.25 \pm 0.13$ & $3.06 \pm 0.03$ & $2.83 \pm 0.02$ & $2.83 \pm 0.02$ & $0.03 \pm 0.01$ & $3.25 \pm 0.03$ \\
\hline S3 & $2.95 \pm 0.06$ & $0.15 \pm 0.01$ & $0.68 \pm 0.07$ & $0.72 \pm 0.01$ & $16.97 \pm 0.37$ & $2.55 \pm 0.04$ & $2.38 \pm 0.12$ & $2.42 \pm 0.06$ & $0.01 \pm 0.01$ & $2.72 \pm 0.03$ \\
\hline S4 & $4.35 \pm 0.12$ & $0.23 \pm 0.01$ & $1.06 \pm 0.04$ & $1.06 \pm 0.04$ & $19.93 \pm 0.58$ & $3.21 \pm 0.13$ & $2.92 \pm 0.15$ & $2.92 \pm 0.15$ & $1.27 \pm 0.51$ & $4.71 \pm 0.64$ \\
\hline S5 & $4.05 \pm 0.52$ & $0.21 \pm 0.03$ & $0.98 \pm 0.15$ & $0.98 \pm 0.15$ & $20.04 \pm 0.59$ & $3.25 \pm 0.11$ & $2.97 \pm 0.15$ & $2.97 \pm 0.15$ & $1.68 \pm 0.79$ & $5.14 \pm 0.85$ \\
\hline S6 & $3.65 \pm 0.58$ & $0.19 \pm 0.03$ & $0.87 \pm 0.17$ & $0.87 \pm 0.17$ & $20.32 \pm 0.68$ & $3.25 \pm 0.09$ & $3.02 \pm 0.18$ & $3.02 \pm 0.18$ & $1.65 \pm 0.71$ & $5.10 \pm 0.77$ \\
\hline
\end{tabular}

The standard deviation of each value was the difference between surface, middle, and bottom water. ${ }^{\text {a }}$ Cations flux of silicates weathering was calculated as the product of $\Phi_{\text {sil }}$ and area of Xiaojiang River basin. ${ }^{b}$ Budgets of $\mathrm{CO}_{2}$ consumption under the assumptions of sulfuric acid completely participated in the weathering of silicates. ${ }^{c}$ Budgets of $\mathrm{CO}_{2}$ consumption based on the assumptions of sulfuric acid completely participated in the carbonates weathering. ${ }^{\mathrm{d}}$ Flux of carbonates weathering derived from the sum of $\mathrm{Ca}^{2+}+\mathrm{Mg}^{2+}$ based on forward model and their stochiometric equivalent of $\mathrm{HCO}_{3}{ }^{-}$. ${ }^{\mathrm{e}}$ The TDS values were determined as the sum of ions that estimated by forward model. ${ }^{\mathrm{f}}$ The values of TDS were calculated as the sum of weathering of silicates, carbonates, and evaporites.

\section{Conclusions}

Based on the major ions concentration of the stratified water of Xiaojiang River in the wet season, the piper diagram was used to analyze the hydrochemical type, and the methods of principal component analysis, ionic mole ratios, and forward model were used to quantify ionic sources. Finally, the chemical weathering rate and $\mathrm{CO}_{2}$ consumption of the basin were estimated, and the following conclusions were drawn:

(1) The hydrochemical type of Xiaojiang River at different depths was consistent $\left(\mathrm{Ca}^{2+}-\mathrm{HCO}_{3}{ }^{-}\right.$ type), and the concentrations of $\mathrm{Ca}^{2+}$ and $\mathrm{HCO}_{3}{ }^{-}$dominated the total cations and anions of stratified water, respectively. This ionic characteristic was similar to that of other rivers in the TGR during wet season.

(2) The ionic composition of river water was mainly controlled by rock weathering, and carbonate weathering had the highest ionic contribution (about 60\%). Evaporites provided about $35 \%$ of the ionic contribution to the reach near the mouth. In addition, the ionic contribution of anthropogenic input to stratified water was not obvious.

(3) Compared with other major tributaries of TGR, Xiaojiang River had a high rock weathering rate. The average weathering rate of carbonates in Xiaojiang River was $19.33 \pm 0.68$ ton $/ \mathrm{km}^{2} /$ year, which was twice higher than the Jialingjiang River and Wujiang River. However, weathering processes in the Xiaojiang River had a limited ability to consume $\mathrm{CO}_{2}$, which accounted for only about $1 \%$ of the $\mathrm{CO}_{2}$ consumption in the TGR basin.

Overall, this study supplements the gaps in hydrochemistry and chemical weathering of stratified water in Xiaojiang River and helps to understand the geochemical characteristics of tributaries under TGR regulation. It also provides a data source for research on the damming impact on global climate change. In order to realize the sustainable development, periodic monitoring of the hydrochemistry of the Xiaojiang River is required in future studies.

Supplementary Materials: The following supporting information can be downloaded at: https: / / www.mdpi.com/article/10.3390/w14030379/s1, Table S1: Hydrochemical parameters of water samples in Xiaojiang River.

Author Contributions: Conceptualization, G.H. and D.W.; methodology, J.Z., X.L. and D.W.; validation, D.W. and G.H.; formal analysis, D.W., J.Z. and X.L.; investigation, B.L., M.H. and Y.W.; data curation, D.W.; writing—original draft preparation, D.W., J.L. and G.H.; writing—review and editing, D.W., G.H. and J.L.; project administration, G.H.; funding acquisition, G.H. All authors have read and agreed to the published version of the manuscript.

Funding: This research was funded by the National Natural Science Foundation of China (No., U1802241, 41325010) and the State Key Laboratory of Simulation and Regulation of Water Cycle in River Basin (SKL2020TS07). 


\section{Institutional Review Board Statement: Not applicable.}

Informed Consent Statement: Not applicable.

Data Availability Statement: The data presented in this study are available in Supplementary Materials.

Acknowledgments: The authors are grateful the group members of Mingming $\mathrm{Hu}$ for their help in sample collection.

Conflicts of Interest: The authors declare no conflict of interests.

\section{References}

1. Fan, Y. Groundwater in the Earth's critical zone: Relevance to large-scale patterns and processes. Water Resour. Res. 2015, 51, 3052-3069. [CrossRef]

2. Regnier, P.; Friedlingstein, P.; Ciais, P.; Mackenzie, F.T.; Gruber, N.; Janssens, I.A.; Laruelle, G.G.; Lauerwald, R.; Luyssaert, S.; Andersson, A.J.; et al. Anthropogenic perturbation of the carbon fluxes from land to ocean. Nat. Geosci. 2013, 6, 597-607. [CrossRef]

3. Luo, W.; Su, L.; Craig, N.J.; Du, F.; Wu, C.; Shi, H. Comparison of microplastic pollution in different water bodies from urban creeks to coastal waters. Environ. Pollut. 2019, 246, 174-182. [CrossRef] [PubMed]

4. Liu, J.; Han, G. Tracing riverine particulate black carbon sources in Xijiang River Basin: Insight from stable isotopic composition and bayesian mixing model. Water Res. 2021, 194, 116932. [CrossRef]

5. Galy, V.; Peucker-Ehrenbrink, B.; Eglinton, T. Global carbon export from the terrestrial biosphere controlled by erosion. Nature 2015, 521, 204-207. [CrossRef]

6. Duvert, C.; Butman, D.E.; Marx, A.; Ribolzi, O.; Hutley, L.B. $\mathrm{CO}_{2}$ evasion along streams driven by groundwater inputs and geomorphic controls. Nat. Geosci. 2018, 11, 813-818. [CrossRef]

7. Maffre, P.; Swanson-Hysell, N.L.; Goddéris, Y. Limited carbon cycle response to increased sulfide weathering due to oxygen feedback. Geophys. Res. Lett. 2021, 48, 4589. [CrossRef]

8. Han, G.; Tang, Y.; Liu, M.; Van Zwieten, L.; Yang, X.; Yu, C.; Wang, H.; Song, Z. Carbon-nitrogen isotope coupling of soil organic matter in a karst region under land use change, Southwest China. Agric. Ecosyst. Environ. 2020, 301, 107027. [CrossRef]

9. Li, S.; Luo, J.; Wu, D.; Jun Xu, Y. Carbon and nutrients as indictors of daily fluctuations of $\mathrm{pCO}_{2}$ and $\mathrm{CO}_{2}$ flux in a river draining a rapidly urbanizing area. Ecol. Indic. 2020, 109, 105821. [CrossRef]

10. Jia, H.; Qu, W.; Ren, W.; Qian, H. Impacts of chemical weathering and human perturbations on dissolved loads of the Wei River, the Yellow River catchment. J. Hydrol. 2021, 603, 126950. [CrossRef]

11. Cao, Y.; Tang, C.; Cao, G.; Wang, X. Hydrochemical zoning: Natural and anthropogenic origins of the major elements in the surface water of Taizi River Basin, Northeast China. Environ. Earth Sci. 2016, 75, 811. [CrossRef]

12. Li, X.; Han, G.; Liu, M.; Liu, J.; Zhang, Q.; Qu, R. Potassium and its isotope behaviour during chemical weathering in a tropical catchment affected by evaporite dissolution. Geochim. Cosmochim. Acta 2022, 316, 105-121. [CrossRef]

13. Fan, H.; He, D.; Wang, H. Environmental consequences of damming the mainstream Lancang-Mekong River: A review. Earth-Sci. Rev. 2015, 146, 77-91. [CrossRef]

14. Raymond, P.A.; Hartmann, J.; Lauerwald, R.; Sobek, S.; McDonald, C.; Hoover, M.; Butman, D.; Striegl, R.; Mayorga, E.; Humborg, C.; et al. Global carbon dioxide emissions from inland waters. Nature 2013, 503, 355-359. [CrossRef] [PubMed]

15. Lauerwald, R.; Laruelle, G.G.; Hartmann, J.; Ciais, P.; Regnier, P.A.G. Spatial patterns in $\mathrm{CO}_{2}$ evasion from the global river network. Glob. Biogeochem. Cycles 2015, 29, 534-554. [CrossRef]

16. Liu, M.; Han, G.; Zhang, Q. Effects of agricultural abandonment on soil aggregation, soil organic carbon storage and stabilization: Results from observation in a small karst catchment, Southwest China. Agric. Ecosyst. Environ. 2020, 288, 106719. [CrossRef]

17. Wang, H.; Sun, F.; Liu, W. Characteristics of streamflow in the main stream of Changjiang River and the impact of the Three Gorges Dam. Catena 2020, 189, 104498. [CrossRef]

18. Herath, I.K.; Wu, S.; Ma, M.; Huang, P. Reservoir $\mathrm{CO}_{2}$ evasion flux and controlling factors of carbon species traced by $\delta^{13} \mathrm{C}_{\mathrm{DIC}}$ at different regulating phases of a hydro-power dam. Sci. Total Environ. 2020, 698, 134184. [CrossRef]

19. Li, S.; Lu, X.X.; He, M.; Zhou, Y.; Li, L.; Ziegler, A.D. Daily $\mathrm{CO}_{2}$ partial pressure and $\mathrm{CO}_{2}$ outgassing in the upper Yangtze River basin: A case study of the Longchuan River, China. J. Hydrol. 2012, 466-467, 141-150. [CrossRef]

20. Zhao, D.; Wang, Z.; Tan, D.; Chen, Y.; Li, C. Comparison of carbon emissions from the southern and northern tributaries of the Three Gorge Reservoir over the Changiiang River Basin, China. Ecohydrol. Hydrobiol. 2019, 19, 515-528. [CrossRef]

21. Chen, Z.; Fang, F.; Shao, Y.; Jiang, Y.; Huang, J.; Guo, J. The biotransformation of soil phosphorus in the water level fluctuation zone could increase eutrophication in reservoirs. Sci. Total Environ. 2021, 763, 142976. [CrossRef] [PubMed]

22. Ding, S.; Chen, P.; Liu, S.; Zhang, G.; Zhang, J.; Dan, S.F. Nutrient dynamics in the Changjiang and retention effect in the Three Gorges Reservoir. J. Hydrol. 2019, 574, 96-109. [CrossRef]

23. Zeng, J.; Han, G. Tracing zinc sources with Zn isotope of fluvial suspended particulate matter in Zhujiang River, southwest China Ecol. Indic. 2020, 118, 6723. [CrossRef] 
24. Pant, R.R.; Zhang, F.; Rehman, F.U.; Wang, G.; Ye, M.; Zeng, C.; Tang, H. Spatiotemporal variations of hydrogeochemistry and its controlling factors in the Gandaki River Basin, Central Himalaya Nepal. Sci. Total Environ. 2018, 622, 770-782. [CrossRef] [PubMed]

25. Liu, W.; Jiang, H.; Shi, C.; Zhao, T.; Liang, C.; Hu, J.; Xu, Z. Chemical and strontium isotopic characteristics of the rivers around the Badain Jaran Desert, northwest China: Implication of river solute origin and chemical weathering. Environ. Earth Sci. 2016, 75, 1119. [CrossRef]

26. Zhao, Y.; Zheng, B.; Wang, L.; Qin, Y.; Li, H.; Cao, W. Characterization of mixing processes in the confluence zone between the Three Gorges Reservoir mainstream and the daning river using stable isotope analysis. Environ. Sci. Technol. 2016, 50, 9907-9914. [CrossRef]

27. Ran, X.; Yu, Z.; Yao, Q.; Chen, H.; Mi, T. Major ion geochemistry and nutrient behaviour in the mixing zone of the Changjiang (Yangtze) River and its tributaries in the Three Gorges Reservoir. Hydrol. Processes 2010, 24, 2481-2495. [CrossRef]

28. Zeng, J.; Han, G. Preliminary copper isotope study on particulate matter in Zhujiang River, southwest China: Application for source identification. Ecotoxicol. Environ. Saf. 2020, 198, 110663. [CrossRef]

29. Chetelat, B.; Liu, C.Q.; Zhao, Z.Q.; Wang, Q.L.; Li, S.L.; Li, J.; Wang, B.L. Geochemistry of the dissolved load of the Changjiang Basin rivers: Anthropogenic impacts and chemical weathering. Geochim. Cosmochim. Acta 2008, 72, 4254-4277. [CrossRef]

30. Kaushal, S.S.; Likens, G.E.; Pace, M.L.; Utz, R.M.; Haq, S.; Gorman, J.; Grese, M. Freshwater salinization syndrome on a continental scale. Proc. Natl. Acad. Sci. USA 2018, 115, E574-E583. [CrossRef]

31. Zeng, J.; Han, G.; Zhang, S.; Liang, B.; Qu, R.; Liu, M.; Liu, J. Potentially toxic elements in cascade dams-influenced river originated from Tibetan Plateau. Environ. Res. 2022, 208, 112716. [CrossRef] [PubMed]

32. Wang, D.; Han, G.; Hu, M.; Wang, Y.; Liu, J.; Zeng, J.; Li, X. Major elements in the upstream of Three Gorges Reservoir: An investigation of chemical weathering and water quality during flood events. Water 2021, 13, 454. [CrossRef]

33. Chen, J.; Wang, F.; Xia, X.; Zhang, L. Major element chemistry of the Changjiang (Yangtze River). Chem. Geol. 2002, 187, $231-255$. [CrossRef]

34. Wang, H.; Li, M.; Sun, C.; Wu, W.; Ran, X.; Zang, J. Variability in water chemistry of the Three Gorges Reservoir, China. Heliyon 2020, 6, e03610. [CrossRef]

35. Jiang, T.; Wang, D.; Wei, S.; Yan, J.; Liang, J.; Chen, X.; Liu, J.; Wang, Q.; Lu, S.; Gao, J.; et al. Influences of the alternation ofwet-dry periods on the variability of chromophoric dissolved organic matter in the water level fluctuation zone of the Three Gorges Reservoir area, China. Sci. Total Environ. 2018, 636, 249-259. [CrossRef]

36. Cui, G.; Li, X.; Li, S.; Zhang, J.; Li, Q.; Huang, J.; Tao, Y. Damming effects on dissolved inorganic carbon in different kinds of reservoirs in Jialing River, Southwest China. Acta Geochim. 2017, 36, 581-597. [CrossRef]

37. Han, G.; Liu, C.-Q. Water geochemistry controlled by carbonate dissolution: A study of the river waters draining karst-dominated terrain, Guizhou Province, China. Chem. Geol. 2004, 204, 1-21. [CrossRef]

38. Zhong, J.; Li, S.-l.; Tao, F.; Yue, F.; Liu, C.-Q. Sensitivity of chemical weathering and dissolved carbon dynamics to hydrological conditions in a typical karst river. Sci. Rep. 2017, 7, 42944. [CrossRef]

39. Zhang, L.; Xia, Z.; Zhou, C.; Fu, L.; Yu, J.; Taylor, W.D.; Hamilton, P.B.; Cappellen, P.V.; Ji, D.; Liu, D.; et al. Unique surface density layers promote formation of harmful algal blooms in the Pengxi River, Three Gorges Reservoir. Freshw. Sci. 2020, 39, 722-734. [CrossRef]

40. Shi, Y.; Xu, G.; Wang, Y.; Engel, B.A.; Peng, H.; Zhang, W.; Cheng, M.; Dai, M. Modelling hydrology and water quality processes in the Pengxi River basin of the Three Gorges Reservoir using the soil and water assessment tool. Agric. Water Manag. 2017, 182, 24-38. [CrossRef]

41. Huang, Y.; Yasarer, L.M.W.; Li, Z.; Sturm, B.S.M.; Zhang, Z.; Guo, J.; Shen, Y. Air-water $\mathrm{CO}_{2}$ and $\mathrm{CH}_{4}$ fluxes along a river-reservoir continuum: Case study in the Pengxi River, a tributary of the Yangtze River in the Three Gorges Reservoir, China. Environ. Monit. Assess. 2017, 189, 223. [CrossRef] [PubMed]

42. Ouyang, W.; Li, Z.; Yang, J.; Lu, L.; Guo, J. Spatio-temporal variations in Phytoplankton communities in sediment and surface water as reservoir drawdown-A case study of Pengxi River in Three Gorges Reservoir, China. Water 2021, 13, 340. [CrossRef]

43. Chen, D.; Chen, H.W. Using the Köppen classification to quantify climate variation and change: An example for 1901-2010. Environ. Dev. 2013, 6, 69-79. [CrossRef]

44. Wang, X.; Guo, J. Change of water environmental capacity in the Xiaojiang River after impoundment of the Three Gorges Reservoir. Res. Environ. Sci. 2012, 25, 36-42. [CrossRef]

45. Tang, H.; Wasowski, J.; Juang, C.H. Geohazards in the Three Gorges Reservoir Area, China-Lessons learned from decades of research. Eng. Geol. 2019, 261, 105267. [CrossRef]

46. Wang, L.-J.; Wu, L.; Hou, X.-Y.; Zheng, B.-H.; Li, H.; Norra, S. Role of reservoir construction in regional land use change in Pengxi River basin upstream of the Three Gorges Reservoir in China. Environ. Earth Sci. 2016, 75, 1048. [CrossRef]

47. Hunt, C.W.; Salisbury, J.E.; Vandemark, D. Contribution of non-carbonate anions to total alkalinity and overestimation of $\mathrm{pCO}_{2}$ in New England and New Brunswick rivers. Biogeosciences 2011, 8, 3069-3076. [CrossRef]

48. Gaillardet, J.; Dupreb, B.; Louvat, P.; Allegre, C.J. Global silicate weathering and $\mathrm{CO}_{2}$ consumption rates deduced from the chemistry of large rivers. Chem. Geol. 1999, 159, 3-30. [CrossRef]

49. Han, G.; Li, F.; Tan, Q. Effects of land use on water chemistry in a river draining karst terrain, southwest China. Hydrol. Sci. J. 2014, 59, 1063-1073. [CrossRef] 
50. Adimalla, N. Groundwater quality for drinking and irrigation purposes and potential health risks assessment: A case study from semi-arid region of south India. Expo. Health 2018, 11, 109-123. [CrossRef]

51. Zeng, J.; Han, G.; Yang, K. Assessment and sources of heavy metals in suspended particulate matter in a tropical catchment, northeast Thailand. J. Clean. Prod. 2020, 265, 121898. [CrossRef]

52. Qu, R.; Han, G.; Liu, M.; Zhang, Q. Vertical distribution and contamination of soil mercury in karst catchment, southwest China: Land-use type influence. Clean-Soil Air Water 2021, 49, 2100061. [CrossRef]

53. Ding, T.; Gao, J.; Tian, s.; Shi, G.; Chen, F.; Wang, C.; Luo, X.; Han, D. Chemical and isotopic characteristics of the water and suspended particulate materials in the Yangtze River and their geological and enviromental implications. Acta Geol. Sin. 2014, 88, 276-360. [CrossRef]

54. Li, X.; Han, G.; Liu, M.; Yang, K.; Liu, J. Hydro-Geochemistry of the river water in the Jiulongjiang River basin, southeast China: Implications of anthropogenic inputs and chemical weathering. Int. J. Environ. Res. Public Health 2019, 16, 440. [CrossRef] [PubMed]

55. Ding, T.; Gao, J.; Tian, S.; Wang, H.; Li, M.; Wang, C.; Luo, X.; Han, D. Chemical and isotopic characters of the water and suspended particulate materials in the Yellow River and their geological and environmental implications. Acta Geol. Sin. 2016, 90, 285-351.

56. Xu, Z.; Shi, C.; Tang, Y.; Han, H. Chemical and strontium isotopic compositions of the Hanjiang Basin Rivers in China: Anthropogenic impacts and chemical weathering. Aquat. Geochem. 2011, 17, 243-264. [CrossRef]

57. Wu, Q.; Han, G. Sulfur isotope and chemical composition of the rainwater at the Three Gorges Reservoir. Atmos. Res. 2015, 155, 130-140. [CrossRef]

58. Dalai, T.K.; Krishnaswami, S.; Sarin, M.M. Major ion chemistry in the headwaters of the Yamuna river system: Chemical weathering, its temperature dependence and $\mathrm{CO}_{2}$ consumption in the Himalaya. Geochim. Cosmochim. Acta 2002, 66, 3397-3416. [CrossRef]

59. Jiang, H.; Liu, W.; Zhao, T.; Sun, H.; Xu, Z. Water geochemistry of rivers draining karst-dominated regions, Guangxi province, South China: Implications for chemical weathering and role of sulfuric acid. J. Asian Earth Sci. 2018, 163, 152-162. [CrossRef]

60. Torres, M.A.; Baronas, J.J.; Clark, K.E.; Feakins, S.J.; West, A.J. Mixing as a driver of temporal variations in river hydrochemistry: 1. Insights from conservative tracers in the Andes-Amazon transition. Water Resour. Res. 2017, 53, 3102-3119. [CrossRef]

61. Dang, C.; Bao, Y.; Jiang, R.; Hu, M.; Zhou, H.; Wang, Y.; Cheng, Y. Heat budget contribute rate in the Three Gorges Reservoir tributary bay between mainstream and tributary using stable isotope analysis. Water Supply 2019, 19, 553-564. [CrossRef]

62. Lewis, Q.; Rhoads, B.; Sukhodolov, A.; Constantinescu, G. Advective lateral transport of streamwise momentum governs mixing at Small River confluences. Water Resour. Res. 2020, 56, 6817. [CrossRef]

63. Kabeya, N.; Kubota, T.; Shimizu, A.; Nobuhiro, T.; Tsuboyama, Y.; Chann, S.; Tith, N. Isotopic investigation of river water mixing around the confluence of the Tonle Sap and Mekong rivers. Hydrol. Processes 2008, 22, 1351-1358. [CrossRef]

64. Subba Rao, N.; Sunitha, B.; Adimalla, N.; Chaudhary, M. Quality criteria for groundwater use from a rural part of Wanaparthy District, Telangana State, India, through ionic spatial distribution (ISD), entropy water quality index (EWQI) and principal component analysis (PCA). Environ. Geochem. Health 2020, 42, 579-599. [CrossRef] [PubMed]

65. Liu, J.; Han, G. Distributions and source identification of the major ions in Zhujiang River, southwest China: Examining the relationships between human perturbations, chemical weathering, water quality and health Risk. Expo. Health 2020, 12, 849-862. [CrossRef]

66. Cui, J.; Zhang, Y.; Yang, F.; Chang, Y.; Du, K.; Chan, A.; Yao, D. Seasonal fluxes and sources apportionment of dissolved inorganic nitrogen wet deposition at different land-use sites in the Three Gorges reservoir area. Ecotoxicol. Environ. Saf. 2020, 193, 110344. [CrossRef]

67. Liang, B.; Han, G.; Liu, M.; Li, X. Zn isotope fractionation during the development of low-humic gleysols from the Mun River Basin, northeast Thailand. Catena 2021, 206, 105565. [CrossRef]

68. Lal, R. Carbon cycling in global drylands. Curr. Clim. Chang. Rep. 2019, 5, 221-232. [CrossRef]

69. Maher, K.; Chamberlain, C.P. Hydrologic regulation of chemical weathering and the geologic carbon cycle. Science 2014, 343, 1502-1504. [CrossRef]

70. Tipper, E.T.; Stevenson, E.I.; Alcock, V.; Knight, A.C.G.; Baronas, J.J.; Hilton, R.G.; Bickle, M.J.; Larkin, C.S.; Feng, L.; Relph, K.E.; et al. Global silicate weathering flux overestimated because of sediment-water cation exchange. Proc. Natl. Acad. Sci. USA 2021, 118, e2016430118. [CrossRef]

71. Moon, S.; Huh, Y.; Qin, J.; Pho, N.v. Chemical weathering in the Hong (Red) River basin: Rates of silicate weathering and their controlling factors. Geochim. Cosmochim. Acta 2007, 71, 1411-1430. [CrossRef]

72. Zhang, S.; Lu, X.X.; Sun, H.; Han, J.; Higgitt, D.L. Major ion chemistry and dissolved inorganic carbon cycling in a humandisturbed mountainous river (the Luodingjiang River) of the Zhujiang (Pearl River), China. Sci. Total Environ. 2009, 407, 2796-2807. [CrossRef] [PubMed]

73. Zhang, L.; Qiao, B.; Wang, H.; Tian, M.; Cui, J.; Fu, C.; Huang, Y.; Yang, F. Chemical characteristics of precipitation in a typical urban site of the hinterland in Three Gorges Reservoir, China. J. Chem. 2018, 2018, 2914313. [CrossRef]

74. Zhu, H.; Li, Y.; Wu, L.; Yu, S.; Xin, C.; Sun, P.; Xiao, Q.; Zhao, H.; Zhang, Y.; Qin, T. Impact of the atmospheric deposition of major acid rain components, especially $\mathrm{NH}_{4}$, on carbonate weathering during recharge in typical karst areas of the Lijiang River basin, southwest China. Appl. Geochem. 2020, 114, 104518. [CrossRef] 